\title{
RELIGIÃO E SEXUALIDADE NO BRASIL: TECNOLOGIAS DE SI E DO EU NA HISTORICIDADE DISCURSIVA DA CONSTRUÇÃO DO SUJEITO BRASILEIRO
}

\author{
RELIGIÓN Y SEXUALIDAD EN BRASIL: TECHNOLOGIES DE UNO MISMO Y DE \\ UNO MISMO EN LA HISTORICIDAD DISCURSIVA DE LA CONSTRUCCION DEL \\ SUJETO BRASILEÑO
}

\begin{abstract}
RELIGION AND SEXUALITY IN BRAZIL: TECHNOLOGIES OF SI AND THE EU IN THE DISCURSIVE HISTORICITY OF THE CONSTRUCTION OF THE BRAZILIAN SUBJECT
\end{abstract}

\author{
Solange Aparecida de SOUZA MONTEIRO ${ }^{1}$ \\ Maria Regina MOMESSO ${ }^{2}$ \\ Monique DELGADO ${ }^{3}$ \\ Paulo Rennes MARÇAL RIBEIRO ${ }^{4}$
}

RESUMO: Objetiva-se refletir o tema da sexualidade a partir da construção discursiva/histórica de seus mecanismos de controle pelas instituições, especialmente a religiosa. De forma linear, destaca-se a história da sexualidade a partir da Antiguidade: de um lado, o Oriente, onde a sexualidade era percebida como iluminação espiritual, de outro, o Ocidente, em especial a filosofia clássica greco-romana, que a aceitava, sem uma imposição moralista, porém o prazer devia ter regramento. Já na Idade Média, a partir do cristianismo, a sexualidade passa a ser compreendida e discursivizada como pecado. Neste período destaca-se a influência da visão de mundo medieval de forma definitiva em nossa moral sexual. Por fim, na história do Brasil, a religião tem influência na moralidade sexual já a partir da colonização e doutrinação jesuítica até as posições oficiais das religiões atuais sobre a sexualidade, sobretudo a posição da Igreja Católica, com o papa Bento XVI. A partir desse olhar na historicidade discursiva, pretende-se também investigar em que medida é possível desenvolver uma compreensão teológica que tenha como pressuposto a abordagem sobre as técnicas de si e

\footnotetext{
${ }^{1}$ Universidade Estadual Paulista (UNESP), Araraquara - SP- Brasil. Doutoranda em Educação Escolar. Pedagoga no Instituto Federal de Educação Ciência e Tecnologia de São Paulo (IFSP), Araraquara - SP - Brasil. Mestra em Processos de Ensino, Aprendizagem e Inovação. ORCID: 〈http://orcid.org/0000-0002-1640-0266>. E-mail: solmonteiro@ifsp.edu.br

${ }^{2}$ Universidade Estadual Paulista (UNESP), Araraquara - SP- Brasil. Docente do Programa de Pós-Graduação em Educação Sexual, e no PPG Educação Escolar da Unesp. Docente FEB-CTI-Unesp. Linguista e líder do Grupo de Pesquisa Gesteld (www.gesteld.com) ORCID: <https://orcid.org/0000-0001-7342-577X>. E-mail: regina.momesso@unesp.br

${ }^{3}$ Universidade Estadual Paulista (UNESP), Araraquara - SP- Brasil. Mestranda em Educação Sexual na Faculdade de Ciências e Letras. Orcid: <https://orcid.org/0000-0002-4115-3762>. E-mail: monique.delgado@bol.com.br ${ }^{4}$ Universidade Estadual Paulista (UNESP), Araraquara - SP- Brasil. Docente do Programa de Pós-Graduação em Educação Sexual, e no PPG Educação Escolar. ORCID: <http://orcid.org/0000-0002-1552-5702>. E-mail: paulo.rennes@unesp.br
} 
as tecnologias do eu empreendidas por Michel Foucault em sua última fase, principalmente em sua obra A hermenêutica do sujeito.

PALAVRAS-CHAVE: Religião. Sexualidade. História. Técnicas de Si. Tecnologias do Eu.

RESUMEN: El objetivo es reflejar el tema de la sexualidad a partir de la construcción discursiva/histórica de sus mecanismos de control por parte de las instituciones, especialmente de los religiosos. De manera lineal, destacamos la historia de la sexualidad desde la antiguedad: Por un lado, Oriente, donde la sexualidad era percibida como iluminación espiritual, por otro, Occidente, en particular la filosofía grecorromana clásica, que la aceptaba, sin una imposición Moralista, pero el placer debe tener reglas. En la Edad Media, desde el cristianismo, la sexualidad se entiende y discursiviza como un pecado. En este período destaca la influencia de la cosmovisión medieval definitivamente en nuestra moral sexual. Finalmente, en la historia de Brasil, la religión tiene una influencia en la moral sexual ya desde la colonización y el adoctrinamiento jesuita a las posiciones oficiales de las religiones actuales sobre la sexualidad, especialmente la posición de la Iglesia Católica, con el Papa Benedicto XVI. Desde esta perspectiva en la historicidad discursiva, también se pretende investigar hasta qué punto es posible desarrollar un entendimiento teológico que asuma el enfoque sobre las técnicas de sí mismo y las tecnologías de la UE emprendidapor por Michel Foucault en Su última fase, principalmente en su trabajo la hermenéutica del sujeto.

PALABRAS CLAVE: religión. Sexualidad. Historia. Técnicas Si. Tecnologías de la Ue.

ABSTRACT: The objective is to reflect the theme of sexuality from the discursive/historical construction of its control mechanisms by institutions, especially religious ones. In a linear way, the history of sexuality from antiquity stands out: on the one hand, the East, where sexuality was perceived as spiritual enlightenment, on the other, the West, especially the classical Greco-Roman philosophy, which accepted it, without a moralistic imposition, but pleasure should be ruled. In the Middle Ages, from Christianity, sexuality becomes understood and discursivized as a sin. In this period stands out the influence of the medieval worldview definitively on our sexual morals. Finally, in the history of Brazil, religion has an influence on sexual morality already from the colonization and Jesuit indoctrination to the official positions of the current religions on sexuality, especially the position of the Catholic Church, with Pope Benedict XVI. From this look at discursive historicity, it is also intended to investigate to what extent it is possible to develop a theological understanding that has as its presupposition the approach on the techniques of himself and the technologies of the self undertaken by Michel Foucault in his last phase, especially in his work A hermeneutics of the subject.

KEYWORDS: Religion. Sexuality. Story. Techniques of Si. I technologies. 


\section{Introdução}

Esta reflexão parte de uma perspectiva histórica aos moldes foucaultianos, ou seja, uma perspectiva de análise que procura obliterar os "idealismos", como a "razão", o "sexo", o "poder" ou a "contradição". Num viés contrário, busca-se questionar a imutabilidade das categorias históricas tradicionais, trazendo para o foco da análise as condições de produção, o caráter situacional do conhecimento histórico, cujo caráter reflete-se na construção do que nos tornamos hoje.

A religiosidade é de significativa importância para os seres humanos. Seja qual for sua religião, não podemos deixar de reconhecer que ela teve/tem forte influência no comportamento e, portanto, na sexualidade humana. É muito útil e primordial conhecer as noções de sexualidade do ponto de vista religioso, em uma perspectiva histórica e na sua historicidade, a fim de provocar uma consciência de seus valores, dificuldades, medos, conflitos, entre outros. De uma maneira díspar, enquanto ainda se apresenta como um viveiro de intensa elaboração, a sexualidade é tema de interesse das religiões e uma questão importante de preocupações éticas debatidas pelos teólogos. Além disso, a religião tem sido um fator determinante na sexualidade humana ao longo da história, às vezes impondo regras rígidas, às vezes buscando orientar o ser humano nessa dimensão tão importante da vida. Paralelamente, a escola, como um todo e como uma das obrigações do Estado, também deve pensar e agir no campo da sexualidade, em todos os níveis possíveis de ação, uma vez que a maior parte do tempo dos discentes, professores e outros funcionários é passado dentro da escola e, por isso, a sexualidade de forma direta e indireta está ali presente. No entanto, quase sempre, esse campo é reduzido a discussões biologizantes e de maneira muito técnica. Isto é verificado, por exemplo, no que diz respeito à contracepção: apenas o uso de métodos contraceptivos como um viés único para evitar a gravidez precoce ou "indesejada" é enfatizado.

Elege-se assim, como pressuposto, que na escola se tem um espaço propício, adequado e importante para a abertura da discussão, do debate entre e com os jovens sobre os tabus, os preconceitos e a sexualidade em geral. Neste espaço é desejável a ampliação dos conhecimentos sobre a vida sexual, sobre a sexualidade de vários ângulos, em especial do ponto de vista histórico, pois esse processo histórico como colocamos acima ajudou a delinear o que somos hoje. Dessa forma, pode-se alargar o espectro sobre a temática e de certa forma torná-la mais crítica e contextualizada.

A orientação teórica foi baseada no julgamento crítico das autoridades sobre o assunto que já possuem notoriedade científica sobre a temática. No que se refere à religião, Peter 
Berguer (1985), por exemplo, analisa a sociologia da religião como uma importante contribuição para o tema desde a "Ética Protestante e o Espírito do Capitalismo" de Max Weber. Ele apresenta como esclarecer várias vezes a relação irônica entre religião e sociedade. Também Emile Durkhein (1996) procura elaborar uma teoria geral da religião, baseada nas instituições religiosas mais simples e primitivas. O autor analisa o sistema de clãs e o totemismo de certas tribos. Ele domina uma teoria da essência da religião e propõe uma interpretação sociológica das formas do pensamento humano. Alphonse Dupront (1976), por sua vez, adota uma abordagem antropológica da religião, afirmando que a antropologia religiosa é erigida como uma ciência do homem religioso e que esta última está em busca do todo-poderoso na religião. Mircea Eliade (2001) descreve um trabalho como introdução geral ao estudo fenomenológico e histórico dos fatos religiosos; ele estuda a situação do homem em um mundo saturado de valores religiosos. Dá uma introdução à história das religiões e um equilíbrio do nosso conhecimento nesta área. Esses autores foram importantes para uma compreensão sociológica, antropológica e histórica da religião. No que diz respeito à sexualidade na escola, para Foucault (2001), o excesso de informação que muitas vezes é transmitido baseia-se na fragmentação do conhecimento.

Logo, a sexualidade é tratada de maneira superficial e imune à reflexão. Todavia, a escola "aborda" a sexualidade mesmo quando não quer, por vezes grosseiramente, seja na arquitetura, na sala de aula, no arranjo dos pátios de recreio ou nos regulamentos elaborados para a vigilância dos alunos. Apresenta-se, no entanto, um momento histórico em que essa maneira com que a escola trata a sexualidade tem de ser explicitada. No entanto, no período atual não se faz mais sentido lidar com sexualidade de forma velada, se queremos um mundo mais maduro e esclarecido, não se pode dar preferência ao implícito em detrimento da explicitação das questões relativas à sexualidade (PINTO, 1999).

No que diz respeito à religião e sexualidade, objeto de estudo, é importante buscar na história uma sequência do tema desde a antiguidade até os dias de hoje, na história geral ou no Brasil. A esse respeito, Peter Brown (1990) trabalha na construção do poder negro da Igreja Católica em sua chamada fase da Igreja primitiva, da sociedade pagã à sociedade cristianizada. O autor aborda como eixo principal as discussões dentro da Igreja primitiva sobre sexualidade e espiritualidade, nomeadamente a continência sexual, o jejum, as peregrinações, o messianismo, o celibato e a virgindade. Santo Agostinho (1995), em seu livro "Virgindade Consagrada" descreve o tema da religião e da sexualidade: seu conteúdo acrescentou algo novo à visão dominante da sexualidade no ambiente eclesial. Neste livro, ele aborda a questão da virgindade, castidade de fornicação e casamento no início do cristianismo. 
A Reforma trouxe grandes novidades para a compreensão da sexualidade na Idade Média, recuperando o significado original da prática da castidade e da virgindade e, portanto, a apreciação e admissão do matrimônio tanto ao leigo quanto ao clero, foi uma das mudanças mais importantes que a Reforma trouxe na vida medieval.

Ronaldo Vainfas (1992), que liderou uma preocupante reflexão sobre temas que contribuíram para a construção da moralidade sexual no Ocidente, desde o cristianismo primitivo até o final da Idade Média, reconstrói, sobre o Brasil, as principais características da moralidade e da sexualidade (1989). Ele habilmente descreve em detalhes como nossos ancestrais fornicaram seus casamentos e jovens, suas práticas homossexuais e repressão sexual. Também no Brasil, Laura de Mello Souza (1986) realizou um estudo sobre feitiçaria nos tempos coloniais. Uma verdadeira arqueologia da religiosidade popular, baseada nos cronistas da época, na devassidão eclesiástica e nos processos da inquisição.

\section{Religião e sexualidade: uma relação de forças e contornos na história e na filosofia}

A religião, em relação à sexualidade, sendo um instrumento ideológico e político-social, orientou os indivíduos para a moralidade, negando sua sexualidade a maior parte do tempo. A principal exceção vem dos orientais, que foram guiados por orientações religiosas do taoísmo, do budismo e do confucionismo, que têm relação com a sexualidade sem a força repressiva das igrejas cristãs. A sociedade oriental foi mais livre e natural que a Ocidental. Religiões e filosofias orientais são baseadas no equilíbrio e na complementaridade entre princípios opostos, simbolizados principalmente pelo "feminino" (yin) e o "masculino" (yang). As mulheres são apresentadas com um suprimento infinito de Yin, enquanto os homens demonstram uma quantidade limitada de Yang. Acredita-se, segundo os orientais, que isso pode ser compensado pelo ato sexual: o homem ao atrasar o orgasmo proporciona à mulher prazer máximo em orgasmos múltiplos, absorvendo muito da energia Yin de seu companheiro. Mais de 2000 anos atrás, na China, no Japão e na Índia, os filósofos indicaram que a sexualidade conferia iluminação espiritual. Esse sexo buscava não apenas o prazer, mas também a transcendência da mortalidade humana.

Os chineses descobriram o equilíbrio na natureza e aplicaram-no em todas as áreas de suas vidas, incluindo a sexualidade. "Desde a $1^{\text {a }}$ Dinastia Chinesa (1750 A.C.), há uma expressão para o sexo: "Nuvens e chuva ". Esta metáfora representa os céus e a terra fazendo amor." (Sexo no mundo oriental). Os gregos e romanos parecem ser bastante liberais. Em Pompeia, gráficos e pinturas que tratam de atividades sexuais são expressos de uma maneira 
mais natural e menos inibitória do que hoje. O pênis é personificado como deus Facsinus, considerado como um símbolo de fertilidade e abundância. Ele foi esculpido em vários tamanhos e materiais, excluído de qualquer conotação obscena e foi encontrado em ambas habitações privadas e edifícios públicos.

Na Grécia, a mitologia e as saídas dos gregos são inexpugnáveis de relações sexuais. Zeus é como um dos deuses mais notáveis nesta área. Numerosos deuses e semideuses em pó, mas com uma força de fertilização masculina, devido aos símbolos da sexualidade: 'Ele pode ver o pensamento de Dionísio, a morte da vida e do vinho. Festas e ritos nas proximidades da Grécia e Roma, responsáveis por esses deuses felizes, orgias e fertilizantes. Também é interessante pensar que os bacantes - pré-condições de Roman Bacchus, identificações com Dionísio -, nas prisões dos sexos com um ponto de animal: um dos dois, mais o sangue derramado, bem como os rituais mágicos e religiosos (LUNA, 2008).

Os gregos são vistos como mais liberais: pelo menos esta é a visão que a maioria do Ocidente tem sobre este povo. "O sexo era natural, divino e sempre era realizado como forma de adoração. Não era descriminado e o senso de pudor não existia porque não havia o "nãodivino" na sexualidade grega" (CROWLEY; LIGVORI, 2008). Esta liberdade está associada a algo natural e não necessariamente libertino, pois consideravam "a atividade sexual, tão profundamente ancorada na natureza e é tão natural que não poderia ser - e Rufos de Éfeso o lembrará - considerada má". (FOUCAULT, 2001).

Os gregos aceitavam a sexualidade sem uma imposição moralista, porém o prazer devia ser regrado, como diz Aristóteles: "é preciso que a faculdade de desejar obedeça à razão como a criança aos mandamentos de seu mestre". (FOUCAULT, 2001).

Entre os gregos também aparece a ideia de sexo associado à procriação, e aí se apresenta a dimensão espiritual da sexualidade associado à pólis. Platão insiste no fato de que: "Tanto um como o outro esposo devem ter em mente (dianoisthai) que eles devem dar à cidade 'as crianças mais belas e melhores possíveis'. Eles devem pensar nessa tarefa intensamente em função do princípio de que os homens são bem sucedidos naquilo que empreendem 'quando refletem e aplicam seu espírito ao que fazem', ao passo que fracassam 'se não aplicarem seu espírito ou se não o possuírem'”. (FOUCAULT, 2001). Em relação à mesma ideia pode-se lembrar o que se encontra nos Problemas do pseudo-Aristóteles: "Se acontece tão frequentemente de os filhos dos humanos não parecerem com seus pais é que estes - no momento do ato sexual - têm a alma agitada de vários modos em vez de só pensar no que fazem nesse instante". (FOUCAULT, 2001). A filosofia estóica que influenciou bastante o cristianismo, e que representa a fase de decadência da filosofia antiga, trabalha com a ideia de controlar racionalmente o 
comportamento emocional. A qualidade do sábio é a indiferença, e a finalidade de sua existência é a apatia, que nasce da supressão do desejo.

O sábio estóico, nas suas relações sexuais, deve despir-se de qualquer emoção, porque se trata de um ato físico e instintivo, assim entendido racionalmente. O próprio casamento passa a ser questionado ao colocar-se a questão do prazer carnal no ato conjugal. Uma das mais fortes consequências disto foi a valorização do celibato. Outra corrente de pensamento que teve grande influência na moral cristã foi o gnosticismo. Pregava que o mundo mau como era só poderia provir do demônio; que um Deus só poderia ter criado a alma. A única solução, diziam os gnósticos, era o manter-se casto. Embora, sob vários aspectos, o cristianismo tenha resistido ao pessimismo gnóstico, ele adota amplamente a idealização da castidade como algo mais próximo de Deus. Na Idade Média a sexualidade foi constantemente abordada. Porém, conforme Foucault, a sexualidade continua ocupando um papel importante nos hábitos sociais, mudando-se apenas sua conotação: fala-se agora da repressão da sexualidade.

$\mathrm{O}$ cristianismo surge do sincretismo das tradições judaicas e neoplatônicas. Torna-se religião oficial do Estado romano no século IV A.C., e assim permanece por dez séculos, período em que o regime escravista do mundo antigo se transforma no regime de vassalagem ou servidão do mundo feudal. Neste momento, a religião (cristã) torna-se sinônimo de doutrina ética, o guia moral que dá unidade às diversas comunidades (feudos). A ética se fundamenta a partir da seguinte concepção metafísica: Deus criador, a verdade é revelada (plano de Deus); os Mandamentos de Deus; a desobediência é igual a pecado; o homem pecador deve buscar a salvação; o sobrenatural tem primazia sobre o natural. A visão teocêntrica faz os valores religiosos impregnar as concepções éticas, e os critérios de bem ou de mal se acham vinculados à fé e dependem da esperança da vida pós-morte. Nas perspectivas religiosas, os valores são considerados transcendentes, pois resultam da doação divina. Identifica-se, então, o homem moral como homem temente a Deus. A consequência disso é a regulação do comportamento moral no mundo material (expiação da culpa do pecado original) para ser premiado (felicidade, liberdade) no mundo imaterial após morte física. Como a sexualidade está no âmbito material é, portanto, fonte de pecado, e deve-se ficar afastado de suas "tentações". É necessário levar uma vida simples e afastada dos prazeres e desejos.

O problema da nova fé era em relação ao casamento: como conseguir manter um dos princípios básicos do cristianismo aceitos na forma do "crescei e multiplicai-vos" sem considerar a atração ou o prazer sexual? “Após advertir duramente contra a imoralidade sexual na segunda parte do capítulo 6 da epístola (versos de 12 a 20), o apóstolo Paulo passa a falar no capítulo 7 dos deveres quanto ao casamento, onde exalta a fidelidade conjugal entre o marido 
e a esposa. Trata daqueles que fazem a sua opção pelo celibato para se dedicarem mais às atividades eclesiásticas, porém recomenda que aqueles que não tenham a vocação para uma vida de castidade que se casassem" (WIKIPÉDIA, 2019). O apóstolo reconhece que o casamento não era um pecado, mas havia muita virtude em renunciar a ele, pois se baseava na premissa de que Eva era de ordem sexual, e o fruto da árvore do conhecimento era o conhecimento carnal.

O sexo agora deveria limitar-se à propagação da espécie e não deveria ser feito por prazer. Conforme Santo Agostinho, no paraíso não havia tensão entre o impulso e o ato sexual.

Foi a partir da danação dos nossos pais primeiros que essa desgraça começou. Parecia-lhe que o casamento, a relação sexual e o Paraíso eram tão incompatíveis como o Paraíso e a Morte. Desse modo, a sexualidade permanecia como o indicador da queda do homem, do seu triste declínio da anterior situação angelical, fazendo com que deslizasse para baixo, para a natureza física, e desta para a sepultura. Está certo que os casais deveriam preocupar-se em gestar filhos, mas que o fizessem conscientes de que estavam cometendo um ato de rebaixamento. Era algo necessário, mas humilhante, que deveria ser praticado sob os acordes de uma intensa melancolia. (BROWN, 1990).

Ainda segundo Santo Agostinho, em função do pecado original, Adão teria violado sua inocência original por ter mantido relações sexuais com Eva. O sexo se transformou numa vergonhosa luxúria, carregado de culpa. No encontro de dois corpos e pela penetração através do contato genital, Agostinho encontrou a explicação para a maneira pela qual o pecado original nos foi transmitido. Assim, para Agostinho "a relação sexual ou mais precisamente o prazer sexual, é o que transmite o pecado original continuamente de geração em geração." (HEINEMANN, 1995, p. 90 apud NASCIMENTO).

Nesta perspectiva, o processo de encarnação e redenção de Jesus é visto também na ótica da sexualidade. Jesus veio ao mundo através de uma santa e milagrosa exceção, que fez do ventre de Maria um habitat sagrado não contaminado pelo sêmen dos descendentes de Adão. Por isso, Jesus também é o redentor da nossa humanidade, pois estaria livre em seu Ser de ter sido contaminado pelo pecado original, desde que este é transmitido pelo ato sexual, do qual Maria não participou.

A Igreja católica, por volta do século XIV e XV, constrói uma outra identidade feminina mítica: a Virgem Maria - Mãe de Cristo, Mãe da Igreja, Mãe dos pobres e infelizes do planeta, que podem ser absolvidos do pecado original, desde que se convertam às normas da Igreja. As mulheres irão alcançar a salvação ao acatar o ideal de feminilidade de Maria, o que pressupõe uma destituição da sexualidade e do prazer, mantendo apenas a função de procriar - o lugar da maternidade, o lugar da Virgem Maria. (LOPES, 2008). 
A crença do pecado original, que levou Santo Agostinho à seguinte reflexão: se a criança, ao nascer, já traz consigo o pecado original, deve-se concluir que o ato sexual engendra não apenas o corpo, mas a alma também, pois o pecado é da alma. A noção do pecado original é tão essencial à Igreja que Jesus teve que ser concebido por mãe virgem, fecundada pelo Espírito Santo. Mas, como a condenação do ato sexual levava a um impasse, pois a proibição do coito determinaria o fim da espécie humana, a saída foi abençoá-lo pelo casamento e eliminar o pecado pelo batismo.

São Tomás, sem nenhuma pretensão de rever a posição de Agostinho, afirmará que “o homem torna-se bestial na cópula, porque não pode moderar com a razão o prazer do coito e a força da concupiscência”. (BENETTI, 1998 p. 297, apud NASCIMENTO). A partir do cristianismo a sexualidade passa, portanto, a ser vista como pecado e apenas admitida no âmbito matrimonial, exclusivamente para a procriação. A copulação deveria servir só para dar a luz. Desta forma, a monogamia e a virgindade para as mulheres passam a ser valorizadas como símbolos de virtude. Se a contracepção era considerada um pecado grave, a homossexualidade era um crime muito maior e, além de um perigo para a Igreja e um repúdio à moralidade cristã, foi também considerada um perigo para o Estado. O "batismo era recusado ao homossexual, assim como a instrução na fé, até que ele houvesse renunciado a seus hábitos malignos" (TANNAHILL, 1980)

O prazer carnal deveria ser evitado e toda a busca do prazer seria condenável, mesmo entre os cônjuges. É nesse aspecto que Santo Agostinho afirmava: “o casamento era desprezível apenas enquanto pretendia buscar o prazer carnal. Porém, se destinado à procriação, o matrimônio constituía-se num bem. Agostinho, assim como seus contemporâneos cristãos, não encontrou uma maneira de articular a possibilidade de o prazer sexual fazer parte e enriquecer as relações entre esposo e esposa". (BROWN, 1990). Na Idade Média a Igreja admite o casamento, porém com menos valor do que o celibato e a virgindade, continua negando o prazer sexual mesmo dentro do casamento, definindo regras em relação às posições sexuais e limitando a frequência de relações sexuais: "Teólogos recomendavam a abstenção nas quintas-feiras, em memória da prisão de Cristo; nas sextas-feiras em memória de sua morte; aos sábados, em honra a Virgem Maria; aos domingos, em homenagem à ressurreição e às segundas-feiras em comemoração aos mortos". (TANNAHILL, 1980).

As posições sexuais também eram controladas pela Igreja Católica, permitindo apenas aquela em que o homem está numa posição superior: os teólogos reconheciam esta posição como a única "natural", sendo todas as outras "antinaturais", porque modelavam o homem ao animal, invertiam a natureza (hierárquica) do homem e da mulher e também porque outras 
posições eram suspeitas de prevenir a concepção e, portanto, contrariarem a natureza do casamento, sendo a contracepção um dos maiores pecados do sexo. (TANNAHILL, 1980).

Foucault (2004) defende que somos herdeiros do cristianismo: nossa subjetividade foi construída ao longo da história sob a égide da conduta sexual, sobre a injunção/coerção de ter de ser dita, confessada, assim como a verdade a ser decifrada, uma verdade ocultada. Acrescenta a essa defesa o argumento de que o Cristianismo apropriou-se das técnicas de si clássicas, em que os indivíduos praticantes do cuidado de si tinham como objetivo principal da transformação de si numa subjetividade autônoma, o homem transformado em obra de arte pautada na verdade encontrada e trabalhada por ele mesmo.

No entanto, o Cristianismo apropria-se das tecnologias de si tornando-as "tecnologias do eu", a verdade agora a ser encontrada está oculta, desloca-se aqui o cuidado de si pelo cuidado pelos outros. Portanto, iniciam-se nesse cuidado pelos outros um jogo da produção da verdade, particularmente a verdade sobre o sexo, por meio, por exemplo, da confissão, assim essa verdade a ser desvendada inclui um não-saber. Todo esse processo histórico da busca do saber a verdade sobre/de si, para saber/poder governar a si e aos outros, engendra, a partir da visão de mundo medieval, a moral cristã, as discussões sobre a sexualidade e as teses de Santo Agostinho, as quais são decisivas para uma moral sexual que tem influência significativa inclusive no Brasil.

\title{
O sexo, a sexualidade e a religião no brasil
}

A Igreja Católica, como instituição e religião oficial do Estado português, chegou ao Brasil em 1500 com Pedro Álvares Cabral. Atuou como co-convocador, junto ao Estado, da tarefa de organizar a colonização do Brasil.

\begin{abstract}
À frente do projeto de expansão luso-cristã estavam os monarcas portugueses a quem, desde meados do século XV, os papas haviam concedido direitos de visita. Em virtude deste direito, a Santa Sé confiou aos reis de Portugal a missão de evangelizar as novas terras estabelecendo a instituição eclesiástica [...]. Explorador e colonizador, os portugueses se consideravam ambos homens de fé. Mas foi uma fé imbuída do espírito da cruzada, segundo a qual a cruz e a espada deveriam caminhar juntas na extensão do reino de Deus. (AZZI, 2001).
\end{abstract}

O poder estabelecido no período colonial promoveu um modelo de catolicismo chamado cristianismo. Esta igreja era uma instituição subordinada ao Estado e a religião oficial funcionava como um instrumento de dominação social, política e cultural. A religião, sem dúvida, tem influência na moralidade sexual brasileira. Nesta era colonial, a Igreja considerava 
a sexualidade como o objeto de sua jurisdição, elevando o sexo conjugal à procriação para uma categoria sagrada e jogando tudo o mais no reino diabólico. Os primeiros padres jesuítas que vêm à colônia discutem a questão da nudez nativa, por exemplo, como algo pecaminoso, porque "os portugueses, quando chegaram ao Brasil, ficaram horrorizados ao ver os índios nus e ver como eles trataram a sexualidade". O discurso religioso jesuítico trabalha com tecnologias do eu no sentido de que devem conduzir os "bons selvagens" à salvação, uma vez que estes encontravam-se no paraíso perdido e ainda não tinham experimentando da "fruta do pecado", ou seja, ainda não detinham o conhecimento, por isso, precisavam ser doutrinados ao modo de pensar cristão, bem como seu valores serem incutidos e respeitados. Essa condução de almas ingênuas e puras era necessária para a salvação do pecado, quase sempre ligado às questões da carne e do sexo.

Desde o início, a situação era preocupante, porque Manuel da Nóbrega, um dos primeiros em uma missão jesuíta recentemente descoberta no Brasil, "implora ao rei que mande mulheres brancas imediatamente para confrontar os portugueses com o sacramento do matrimônio. E essa era a urgência que até aceitaria o descrédito das mulheres" (VAINFAS,1998). Do ponto de vista medieval do mundo, a Igreja impôs ao Brasil uma moralidade sexual de condenar os costumes indígenas e impor comportamentos rígidos, limitando a sexualidade. É verdade que, em todo caso, os agentes eclesiásticos da colonização tentaram por todos os meios tornar o Brasil parte legítima da cristandade romana, o que implicou, entre outras coisas, difundir o modelo do matrimônio cristão: uniões sacramentais, família conjugal, continência e austeridade.

Eles tentaram com os índios e depois com os africanos. Vindo aqui em busca de aventura, ficaram, no entanto, frustrados pelos interesses comerciais da colonização, pela escravidão, pelo hibridismo cultural que a colônia brasileira possuía por vocação. (VAINFAS, 1998). Os padres jesuítas sempre se esforçaram para exercer a catequese, a cultura sexual local se opondo aos costumes cristãos. "O frenesi sexual era em primeiro lugar entre os índios: sempre nu, polígamo, incestuoso" (VAINFAS, 1998).

As índias, depois os escravos, alimentaram a sede de devassidão que assola os trópicos. Segundo a Igreja, esse deboche ocorreu por bigamia, adultério, sodomia, zoofilia. Portanto, era obrigação da Igreja pôr fim a tal situação. O Santo Ofício impôs um comportamento sexual condenando a homossexualidade, o casamento de padres, a contracepção e o prazer sexual em geral, especialmente entre as mulheres, e impõe normas que pró́bem a discussão de certos tópicos com os quais não é acordado. 
Vários casos envolvendo a homossexualidade no Brasil colonial foram relatados. Os cadernos de Nefando incluíam casos de sodomia. E ele explica que o mais temido não era derramar esperma no chamado "navio proibido", mas que a alternativa sexual deveria ser erradicada porque favorecia a destruição do casamento, pregava o livre prazer, impedia a procriação. (OLIVEIRA, 2008).

O professor Ronaldo Vainfas (1998) relata que os atos nocivos das classes baixas eram pouco preocupantes, tendo a salvação espiritual pouca ou nenhuma importância. Menos ainda foram os ensaios envolvendo o clero e as mulheres brancas. Os religiosos, pecadores ou não, eram muito úteis no processo de colonização e, para as poucas mulheres, não podiam faltar homens, porque eram necessários para o casamento e concubinato, para a colonização da terra. "O reconhecimento e a apreciação do sexo e da vida conjugal foram completamente diferentes para os negros, brancos e indianos. Entre os negros e indianos, a fertilidade era encorajada, os sindicatos não legalizados eram aceitos e as famílias muitas vezes eram reduzidas a mulheres e crianças. Entre os brancos, o casamento deveria seguir o padrão das uniões legais e monogâmicas em que eles valorizavam, especialmente a virgindade e a fidelidade das mulheres. "(DEL PRIORE, 2001).

O Brasil era uma terra de índios e negros, com escassez de mulheres brancas para o casamento. A colônia tornou-se assim um paraíso para as pessoas que buscavam satisfação sexual, as quais eram fortemente reprimidas em Portugal. Chegados na colônia, os portugueses logo tentaram se comunicar publicamente com vários índios, porque era um procedimento comum para quem chegava aqui. E durante as horas devotadas ao credo, pediram perdão a Deus para atacar os índios que, seminus e disponíveis, estavam a caminho. (OLIVEIRA, 2008). Dos primeiros jesuítas ao trabalho do Santo Ofício, a Igreja Católica procurou discutir, condenar e controlar as práticas sexuais. Foi discutido e codificado se o ato denunciado fosse um erro, um pecado ou um crime; o grau de punição - por exemplo, morte ao fogo, castração, confisco de propriedade, degradação; e a extensão do ato - se houvesse descarga de esperma, se houvesse apenas derrames nos genitais, se fossem apenas homens com boas maneiras e roupas, se fosse uma relação entre mulheres. Que o crime ou o pecado não consiste em uma sodomia, um nome dado à vasta lista de atos sexuais excluindo a penetração anal ou vaginal, como a masturbação, o sexo oral e desvio sexual. (RIBEIRO, 2008).

A Colônia dos séculos XVI e XVII era altamente erótica, de extrema liberdade sexual, mas a Igreja impôs uma moral sexual a partir de uma visão medieval de mundo, agindo com poderes para investigar qualquer denúncia que implicasse no não cumprimento das leis e normas da Igreja Católica relacionadas à vida cotidiana da população. O Estado Brasileiro 
durante o período imperial assumiu o regime do padroado e o Brasil era um país confessional, de religião oficial Católica, e assim a Igreja estava claramente atrelada ao Estado. "A Religião Católica Apostólica Romana continuará a ser a Religião do Império. Todas as outras religiões serão permitidas com seu culto doméstico ou particular, em casas para isso destinadas, sem forma alguma exterior de tempo". (Art. $5^{\circ}$ Constituição de 1824). A moral imposta pela igreja na era colonial é também o tempo, depois, em um momento de importante debate sobre o modelo da sociedade, consciente das ideias liberais do Iluminismo, mas com as possibilidades de um novo clima cultural, no entanto, aqui no Brasil, com a proclamação da república, ocorreu a separação da igreja e do estado. A Igreja na região para assim reconectar a Igreja Católica e outras igrejas e dar-lhes o direito de organizar e realizar sua missão.

Em relação à moral, a Igreja continuou a impor as suas normas, impedindo as discussões sobre tudo o que não concordava. Dessa forma, a normatização da sexualidade continuou sob seu controle. A Igreja influenciou definitivamente a nossa moral sexual. Uma moral que foi estabelecida a partir do Concílio de Trento, mas que a Igreja manteve rigidamente suas posições até os dias atuais. Hoje a essência deste modelo é defendida fervorosamente pela Igreja, que continua tentando estabelecer valores sexuais, preocupada em moldar e controlar o comportamento humano, mas esse paradigma está em crise na medida em que as leis tendem a adaptar-se aos novos hábitos e aos novos comportamentos em função das transformações econômicas, políticas, sociais e tecnológicas, que a Igreja já não pode conter.

\section{Posições de algumas religiões em relação à sexualidade}

É sabido que a forma como as religiões lidam com o tema da sexualidade na sociedade acontece de maneira diversa. Desde as perspectivas doutrinárias e cosmológicas estão em jogo, além de suas tradições religiosas, os modos de ver, sentir e dizer sobre a verdade que ronda a sexualidade e o sexo. Tudo isso traz consequências sociais e políticas. $\mathrm{O}$ desafio que aqui se coloca diz respeito ao impasse referente a conciliar diferentes convicções com as responsabilidades sociais atuais. Expõe aqui um panorama geral de posições religiosas sobre a sexualidade.

O Professor Ronaldo Vainfas (1998), informa que não havia muita preocupação com os atos nefandos das classes inferiores e de cor, já que sua salvação espiritual era de pouca ou nenhuma importância. Mais raros ainda eram processos envolvendo pessoas ligadas ao clero e mulheres brancas. Os religiosos, pecadores ou não, eram muito úteis no processo colonizador, 
e quanto às mulheres, por seu escasso número, não podiam faltar aos homens, já que necessárias para o casamento e para o concubinato, em favor do povoamento da terra.

O reconhecimento e a valorização da vida sexual e matrimonial eram completamente diferentes para negros, brancos ou índios. Entre negros e índios a fecundidade era estimulada, aceitavam-se uniões não legalizadas e famílias que muitas vezes se resumiam a mulher e filhos. Entre os brancos, o casamento devia seguir o padrão das uniões legais e monogâmicas, em que se valorizavam, sobretudo a virgindade e a fidelidade das mulheres. (DEL PRIORE, 2001).

Assim, os posicionamentos das religiões sobre o tema sexualidade e sexo determinam os modos de ver, pensar, sentir e agir a despeito da temática. Cada sujeito vinculado a uma determinada religião constitui-se a partir dos valores, dos mitos, das narrativizações de si e dos outros, que formam a base dessa religião. Logo, todo imaginário e o simbólico desse sujeito é afetado em maior ou menor medida no posicionamento que sua religião possui a propósito desse tema.

Aliado ao posicionamento das religiões em relação à temática, temos por parte do arcabouço doutrinário de cada religião tecnologias de si ou tecnologias do eu, as quais são utilizadas como forma de "cuidado de si" para emancipação do indivíduo, e/ou como "cuidado pelos outros", que objetiva a sujeição do indivíduo a padrões de conduta alheias a vontade dos indivíduos.

Interessante notar, também, que esse "cuidado pelos outros" quase sempre está estabelecido num lugar tênue com a aparência do "cuidado de si". Comumente, por exemplo, o sujeito passa a ser trabalhado num jogo de verdade, que não o leva a pensar sobre si nesta relação dele mesmo com a verdade: "a verdade" pode ser construída, por exemplo, pela verossimilhança, como o simples uso de uma determinada cor para determinar macho/ fêmea.

\section{À guisa das considerações: a religião e as técnicas de si}

O próprio pensamento é uma tarefa a ser empreendida pelo sujeito como uma exegese de si. Para os helenísticos, os exercícios, como os de decomposição do tempo, visavam elaborar uma noção de temporalidade em que o presente é tomado como oportunidade de o indivíduo garantir sua liberdade em relação ao que o cerca. É preciso que se vejam as coisas em sua diversidade e descontinuidade, como uma dispersão, não em sua unidade. Esse princípio deve ser aplicado à vida toda, inclusive a si mesmo, afinal o sujeito também possui um modo de ser marcado pela descontinuidade. O único elemento de fixação de identidade do sujeito é a virtude, que é vista como uma força de coesão da alma, como uma falsa unidade. A única unidade de 
que somos capazes e que pode nos fundar naquilo que somos, a identidade de sujeito que podemos e devemos ser em relação a nós mesmos, é somente aquela que somos enquanto sujeito razoáveis, isto é, nada mais que a razão que preside o mundo. Consequentemente, se olharmos abaixo de nós, ou antes, se olharmos a nós mesmos de cima para baixo, nada mais somos que uma série de elementos distintos um dos outros: elementos materiais, instantes descontínuos. Mas se tentarmos nos apreender como princípio razoável e racional, perceberemos então que nada mais somos senão parte de algo que é a razão presidindo o mundo inteiro. Os exercícios espirituais tanto tinham como finalidade a dissolução da individualidade quanto estabelecer a identidade do sujeito. O sentido era de aplicar o espírito a si mesmo e isso não significava estabelecer um saber sobre a interioridade do sujeito, mas proporcionar uma mobilização do saber que provocasse um deslocamento do sujeito até um ponto elevado em que pudesse perceber a si mesmo, que possibilitasse a esse sujeito apreender as coisas em sua realidade e valor, que possibilitasse ao sujeito apreender-se a si mesmo em sua própria realidade.

Foucault, (2001) “O sujeito deve perceber-se na verdade do seu ser.” Esse saber permite que o sujeito não só encontre a sua liberdade como também que, sendo livre, encontre a felicidade e a perfeição para as quais é capaz. Esse saber da espiritualidade é que foi sendo pouco a pouco apagado para dar lugar ao saber do conhecimento na modernidade. "Deste saber do conhecimento, o sujeito nada pode esperar para a sua transfiguração." Porém, esse saber da espiritualidade desaparecerá completamente com o Iluminismo. Para Foucault (2001), se concentra na análise da prática de si, na ação que está implicada nessa conversão de si, da filosofia helenística, que tem a ver com aquisição da virtude. Essa ação está ligada a um saber prático, que é resultado de um esforço, de um treinamento, como uma arte de si: a áskesis. Trata-se de uma maneira de ligar o sujeito à verdade, como uma prática da verdade que possibilita descobrir "em que medida o fato de conhecer a verdade, de dizer a verdade, de praticar e de exercer a verdade, pode permitir ao sujeito não somente agir, mas ser como deve ser e como quer ser". O que está envolvido na ascese helenística é: a "constituição de um saber sobre o mundo como experiência espiritual do sujeito", a "constituição do sujeito como fim último para si mesmo através e pelo exercício da verdade”. Isso difere da proposta da modernidade que exige um saber objetivante que impõe ao sujeito um conhecimento e a sujeição do mesmo a uma ordem.

A história da subjetividade comporta um processo de transformação lenta em que se deu essa passagem da espiritualidade do saber e da prática da verdade para o estado do domínio do conhecimento pelo sujeito e a sujeição a uma lei. A áskesis era, de início, essa espiritualidade do saber bem como essa prática e exercício da verdade. Essa ascese (áskese) difere também da 
ascese cristã, baseada na renúncia a si, visto que estava voltada para uma "constituição de uma relação plena, acabada e completa de si para consigo". Trata-se de dotar o sujeito do que ele não possui e de prepará-lo para os imprevistos do futuro. "Na espiritualidade antiga, sobretudo no estoicismo, a prática ascética e suas diferentes técnicas de si visam à subjetivação das enunciações verdadeiras por meio da transformação no modo de ser do sujeito ouvinte, escriturante e dirigido".

É possível traçar uma comparação entre o sábio e o atleta na medida em que ambos precisam estar preparados apenas para aquilo com que vão se deparar. No cristianismo, esse preparo visa, no entanto, a uma trajetória progressiva em direção à santidade, a uma superação de si a ponto de renunciar-se a si. Como um atleta, o cristão tem um inimigo, que é ele mesmo, com quem terá que enfrentar perigos como o pecado, a sua natureza decaída e as investidas diabólicas, ao contrário da espiritualidade antiga, que envolvia também uma luta, mas contra os acontecimentos do mundo exterior. "O atleta antigo é um atleta do acontecimento. Já o cristão é um atleta de si mesmo.”. Essa preparação do indivíduo - uma paraskué - consiste, portanto, em: uma aprendizagem de alguns movimentos necessários a uma arte de viver, uma atividade discursiva que visa dotar o sujeito da capacidade do dizer verdadeiro a partir da aquisição de frases (lógoi) fundadas na razão, ou seja, princípios aceitáveis de comportamento como se essas frases falassem por ele, a um modo de ser constituído por esse discurso persuasivo que se integra ao indivíduo e comanda sua ação.

O que está implicado nessa preparação é a transformação dos discursos verdadeiros em princípios de comportamento, a transformação do lógos em êthos, de modo que a ascese seja compreendida como aquilo que faz com que o dizer verdadeiro se torne o modo de ser do sujeito. "Constituir-se a si mesmo por um exercício em que o dizer verdadeiro se torna o modo de ser do sujeito.”. Foucault (2001), deixa claro que o objetivo da ascese filosófica do período helenístico é: colocar o sujeito como fim último de sua própria existência, equipar o sujeito para enfrentar os acontecimentos possíveis da vida, e ligar o sujeito à verdade. Isso difere de tudo o que se tem hoje por ascese, principalmente pela influência do ascetismo cristão. Essa ascese filosófica pagã é o que permite, de um lado, adquirir os discursos verdadeiros, dos quais se tem necessidade em todas as circunstâncias, acontecimentos e aventuras da vida, a fim de estabelecer uma relação adequada, plena e acabada consigo mesmo; de outro lado, e ao mesmo tempo, a ascese é o que permite fazer de si mesmo o sujeito destes discursos verdadeiros, é o que permite fazer de si mesmo o sujeito que diz a verdade e que, por esta enunciação da verdade, encontra-se transfigurado, e transfigurado precisamente pelo fato de dizer a verdade. 
A ascese da prática de si tem for função o que Foucault chama de subjetivação do discurso verdadeiro, que faz com que o indivíduo se torne o sujeito do discurso verdadeiro. A ascese cristã, porém, propõe algo diferente disso, que é a renúncia de si, ao dar ênfase a um momento em que pode se ver uma objetivação de si em um discurso de verdade, que é o momento da confissão. Os procedimentos de subjetivação do discurso verdadeiro visam a que o sujeito apreenda os discursos que recebeu como verdades que são suas a ponto de tornar-se sujeito da enunciação do discurso verdadeiro. Envolvem práticas de escuta, de leitura, de escrita e de fala que oferecem o suporte para esse modo de ascese. A escuta é o primeiro momento dessa prática de si em que a verdade é apreendida pelo sujeito e que se constitui assim como seu êthos. É um exercício que comporta uma ambiguidade visto que envolve o sentido da audição e a percepção do lógos, uma relação entre uma atitude passiva de recepção que não pode estar dissociada de uma atividade racionalmente articulada como a fala. "Portanto, ambiguidade fundamental da audição: pathetikós e logikós.".

Esse esquema ambíguo faz com que a escuta comporte riscos, uma vez que está sempre sujeita a equívocos e falta de atenção. Como a ascese da escuta é o que dá acesso à verdade, é preciso que se faça uso de uma certa arte, uma habilidade adquirida e uma prática assídua que possibilite a reflexão e a purificação da escuta. É preciso que se observe o silêncio: é preciso primeiramente escutar sem intervir. É preciso que se desenvolva uma atenção fixa como uma imobilidade do corpo que possa garantir a qualidade da atenção. Essa imobilidade do corpo tem uma função moral de evidenciar um certo domínio de si. É preciso que se assuma um compromisso, uma manifestação de vontade de se sustentar o discurso verdadeiro. Trata-se, portanto, de uma ética da escuta que tem por objetivo fazer com que o sujeito apreenda o que ouviu, faça um exame de si e lance um olhar sobre si mesmo. A alma que escuta deve vigiar a si mesma. Prestando atenção como deve àquilo que ouve, ela presta atenção, no que ouve, à significação às crises que a teologia enfrenta na pós-modernidade.

O que se depreende a partir das provocações de Foucault é que as crises que a teologia hoje enfrenta são decorrentes dos próprios discursos de autonomia engendrados na cultura ocidental, ou seja, são consequências da modernidade, uma vez que esta foi construída a partir das interferências cristãs sobre a cultura ocidental. Outra questão que continua em aberto é se Michel Foucault é um bom interlocutor para a teologia. Uma vez que desenvolve uma crítica sobre as circunstâncias históricas em que se deu a relação sujeito e objeto, a análise de Foucault torna-se imprescindível para a compreensão desse tempo e do modo como os saberes são construídos tendo em vista a legitimação de uma verdade. Embora sua crítica seja contundente e aponte para uma rejeição da experiência cristã e da moralidade que se construiu em torno da 
religião, suas provocações inquietam e exigem da teologia uma resposta que precisa sempre ser atualizada.

\section{REFERÊNCIAS}

AGOSTINHO, Santo. A virgindade consagrada. São Paulo: Paulinas, 1990. selecionadas. v. 5. São Leopoldo: Sinodal, 1995.

BERGER, Peter L. O Dossel Sagrado elementos para uma teoria sociológica da religião. São Paulo: Paulinas, 1985.

BROWN, Peter. Corpo e sociedade. O homem, a mulher e a renúncia sexual no início do cristianismo. Rio: Zahar, 1990.

DUPRONT, Alphonse. In: LE GOFF, Jacques; NORA, Pierre (orgs.). História: novos objetos, novas abordagens, novos problemas. Rio de Janeiro, Francisco Alves. 1976.

DURKHEIN, Émile. As formas elementares da vida religiosa. São Paulo Martins Fontes, 1996.

ELIADE, Mircea. O sagrado e o profano: a essência das religiões. São Paulo,Martins Fontes, 2001.

FOUCAULT, M. A hermenêutica do sujeito. São Paulo: Martins Fontes, 2004.

FOUCAULT, M. História da Sexualidade: a vontade de saber. Rio de Janeiro: Graal, 2001.

FOUCAULT, M. O sujeito e o poder. In: DREYFUS, H.; RABINOW, P. Michel Foucault uma trajetória filosófica. Rio de Janeiro: Forense Universitária, 1995. p. 231-249.

LUTERO, Martinho. Ética - Fundamentos, Oração, Sexualidade. Vol. 5 Sindal, 1995.

PINTO, Elizabeth Baptista. Orientação Sexual na Escola: a importância da Psicopedagogia nessa nova realidade. São Paulo:Gente,1999.

SOUZA, Laura de Mello. O Diabo e a Terra de Santa Cruz. Ed. Companhia das Letras, 1986.

VAINFAS, Ronaldo. Casamento, Amor e Desejo no Ocidente Cristão. Ed. Ática, 1992.

VAINFAS, Ronaldo. Trópico dos Pecados: moral, sexualidade e Inquisição no Brasil Colônia. Rio de Janeiro: Campus, 1989. 


\section{Como referenciar este artigo}

SOUZA MONTEIRO, Solange Aparecida de; MOMESSO, Maria Regina; DELGADO, Monique; MARÇAL RIBEIRO, Paulo Rennes. Religião e sexualidade no brasil: tecnologias de si e do eu na historicidade discursiva da construção do sujeito brasileiro. Rev. Sem Aspas, Araraquara, v. 8, n. 1, p. 131-149, jan./jun. 2019. e-ISSN: 2358-4238. DOI: 10.29373/sas.v8i1.13204

Submetido em: 24/03/2019

Aprovado em: 29/05/2019 